\title{
Adhesion of Gallibacterium anatis to Chicken Oropharyngeal Epithelial Cells and the Identification of Putative Fimbriae
}

\author{
Mónica L. Salgado Lucio ${ }^{1}$, Sergio Vaca ${ }^{1 *}$, Candelario Vázquez ${ }^{2}$, Edgar Zenteno ${ }^{3}$, Ismael Rea ${ }^{1}$, \\ Víctor M. Pérez-Márquez ${ }^{4}$, Erasmo Negrete-Abascal ${ }^{1}$ \\ ${ }^{1}$ Carrera de Biología, Facultad de Estudios Superiores Iztacala, Universidad Nacional Autónoma de México (UNAM), \\ Tlalnepantla, México \\ ${ }^{2}$ Centro de Investigaciones en Ciencias Microbiológicas, Benemérita Universidad Autónoma de Puebla (BUAP), Puebla, México \\ ${ }^{3}$ Departamento de Bioquímica, Facultad de Medicina, Universidad Nacional Autónoma de México, México City, México \\ ${ }^{4}$ Biotecnología Veterinaria, Tehuacán, Mexico \\ Email: *vacasergio@gmail.com
}

Received October 4, 2012; revised October 28, 2012; accepted November 10, 2012

\begin{abstract}
Microbial infections are typically initiated by the colonization of tissues by a specific mechanism that promotes adherence to host cells or tissues. In this work, we characterized the ability of Gallibacterium anatis $\mathrm{F} 149^{\mathrm{T}}$ to express fimbriae that may be involved in mucosal attachment. Using transmission electron microscopy, the fimbriae-like structures could be observed on the surface of negatively stained G. anatis $\mathrm{F} 149^{\mathrm{T}}$, and these structures were further visualized after being released by physical shaking. When the fimbriae-like structures were separated by SDS-PAGE, the proteins comprising them were isolated and sized at 13 and $25 \mathrm{kDa}$. G. anatis $\mathrm{F} 149^{\mathrm{T}}$ was able to adhere to chicken oropharyngeal epithelial cells. Adhesion could be completely inhibited by pretreatment of the bacterial cells with trypsin, whereas $25 \%$ inhibition was attained after pretreatment with an antiserum against the $13 \mathrm{kDa}$ protein. We demonstrated by immuno-gold electron microscopy that the antibodies from the antiserum were specifically associated with the fimbria-like structures on G. anatis. These results indicated that G. anatis $\mathrm{F} 149^{\mathrm{T}}$ expresses fimbriae that contribute to its adhesion to chicken oropharyngeal epithelial cells and may be important for colonization of the upper respiratory tract.
\end{abstract}

Keywords: G. anatis; Adhesion; Fimbria; Pili

\section{Introduction}

Gallibacterium anatis belongs to the Pasteurellaceae family and is a common bacterium found in the upper respiratory tract and lower reproductive tract of healthy chickens and turkeys [1-3]. Several authors have associated $G$. anatis to pathological conditions, such as salpingitis, peritonitis, septicemia, pericarditis, hepatitis, enteritis, and respiratory tract lesions [4-6]. Most recently, Neubauer and co-workers [7] found that G. anatis was an agent that was very frequently associated with peritonitis and/or salpingitis in free-range laying hens showing clinical symptoms of the above mentioned lesions.

Limited insight has been obtained into the factors that allow the persistence of G. anatis on the mucosal membranes of its host and the factors that affect its ability to occasionally cause disease. The ability to secrete $\operatorname{IgG}$ degrading proteases [8], agglutinate red blood cells [9], and produce a cytolytic RTX-toxin $[10,11]$ appear to be

${ }^{*}$ Corresponding author. the most important factors during interaction with the host. We recently used scanning electron microscopy to demonstrate the ability of $G$. anatis to adhere to plastic surfaces and form a biofilm on glass; this work also indicated the presence of at least two different fimbriaelike structures [12].

In this paper, we show that $G$. anatis $\mathrm{F} 149^{\mathrm{T}}$ expresses fimbriae that contribute to adhesion to chicken oropharyngeal epithelial cells and may be important for the colonization of the chicken upper respiratory tract.

\section{Materials and Methods}

\subsection{Bacterial Strain and Media}

The non-hemolytic type strain Gallibacterium anatis biovar anatis F149 ${ }^{\mathrm{T}}$ (ATCC $43329^{\mathrm{T}}$ ) was used in this study. Propagation of bacteria on solid media was performed using 5\% sheep blood agar (BD Bioxon, Becton Dickinson, Cuautitlán Izcalli, Mexico, Mexico). Bacteria were incubated at $37^{\circ} \mathrm{C}$ overnight in an incubator (Lab-Line) 
with $5 \% \mathrm{CO}_{2}$. Brain-heart infusion broth (BHI; BD Bioxon) was used for propagation of bacterial cultures in liquid media.

\subsection{Fimbrial Protein Isolation}

Isolation of $G$. anatis $\mathrm{F} 149^{\mathrm{T}}$ fimbrial proteins was performed by transferring bacterial cells that were incubated in BHI overnight to a $1 \mathrm{~L}$ flask containing $500 \mathrm{~mL}$ of BHI medium supplemented with $1 \%$ sheep blood. This mixture was incubated at $37^{\circ} \mathrm{C}$ without shaking for $48 \mathrm{~h}$. Subsequently, bacterial and blood cells were collected by centrifugation at $8000 \times \mathrm{g}$ for $20 \mathrm{~min}$. The cell pellet was washed 3 times with $50 \mathrm{mM}$ phosphate buffered saline (pH 7.4) to eliminate red blood cells. The bacterial cells were resuspended in $20 \mathrm{mM}$ Tris- $\mathrm{HCl}, 25 \mathrm{mM} \mathrm{NaCl}, \mathrm{pH}$ 8.0 , followed by 10 minutes of vigorous shaking by hand to release surface structures. The bacterial cells were removed by centrifugation at $5000 \times \mathrm{g}$ for $30 \mathrm{~min}$ at $4^{\circ} \mathrm{C}$. Proteins from the clear supernatant were concentrated by precipitation with $2 \%$ polyethylene glycol (PEG) 8000 and $5.8 \% \mathrm{NaCl}$ at $4{ }^{\circ} \mathrm{C}$ overnight. Precipitated proteins were collected by centrifugation at $11,000 \times \mathrm{g}$ for $30 \mathrm{~min}$ at $4^{\circ} \mathrm{C}[13]$.

\subsection{Electrophoresis}

The protein preparations were boiled for $5 \mathrm{~min}$ in a sample buffer containing 5\% 2-mercaptoethanol and subsequently separated by electrophoresis on a $15 \%$ sodium dodecyl sulfate-polyacrylamide gel in a buffer system as previously described by Laemmli [14]. After electrophoresis, polyacrylamide gels were stained with Coomassie Brilliant blue solution.

\subsection{Polyclonal Antibodies}

A polyclonal antiserum against $G$. anatis was obtained as follows: 4-week-old SPF chickens were experimentally infected with a $G$. anatis field isolate (249101) obtained from the kidney of a 24-week-old commercial Leghorn laying chicken. An overnight culture $\left(10^{9} \mathrm{CFU} / \mathrm{mL}\right.$ of this bacterium was prepared as described above, and an aliquot $(0.2 \mathrm{~mL})$ was injected intravenously into each bird. Inoculated birds were kept for 10 days post inoculation.

To obtain polyclonal antibodies against $G$. anatis $\mathrm{F} 149^{\mathrm{T}}$ fimbriae, polyacrylamide gels bands containing the 13 or $25 \mathrm{kDa}$ proteins were cut, dried, and suspended in a $0.85 \%$ saline solution. Proteins were mixed with Freund's complete adjuvant, and $30-40 \mu \mathrm{g}$ of protein was then injected subcutaneously into Wistar rats. These rats received three booster injections of $30-40 \mu \mathrm{g}$ of protein mixed with Freund's incomplete adjuvant at twoweek intervals as previously described [15]. Experimental work followed the guidelines of the Norma Official Mexicana Guide for the use and care of laboratory ani- mals (NOM-062-ZOO-1999).

\subsection{Western Blotting}

The fimbrial preparations were electrophoresed and transferred to nitrocellulose membranes (Bio-Rad) as previously described [15]. Membranes were blocked with $5 \%$ skim milk and incubated with rat polyclonal sera against the 13 or $25 \mathrm{kDa}$ proteins, or a pooled serum from the chickens experimentally infected with live $G$. anatis. Specific binding of the sera was identified with peroxidase-labeled rabbit IgG anti-chicken or goat antirat antibodies using diaminobenzidine and $\mathrm{H}_{2} \mathrm{O}_{2}$ as substrates.

\subsection{Transmission Electron Microscopy}

G. anatis strain $\mathrm{F} 149^{\mathrm{T}}$ was incubated on $5 \%$ sheep blood agar or in liquid BHI medium under stationary conditions. Bacterial cells were suspended in $50 \mathrm{mM}$ Tris- $\mathrm{HCl} \mathrm{pH}$ 8.0, $25 \mathrm{mM} \mathrm{NaCl}$ containing 5\% glutaraldehyde (Sigma), incubated at room temperature for $2 \mathrm{~h}$ and washed 3 times with $50 \mathrm{mM}$ Tris- $\mathrm{HCl} \mathrm{pH} 8.0,25 \mathrm{mM} \mathrm{NaCl}(2000$ $\mathrm{rpm} / 10 \mathrm{~min}$ each time). Fixed whole bacterial cells or aliquots containing the putative fimbriae were placed on carbon- and formvar-coated copper grids, stained with $1 \%$ (wt/vol) phosphotungstic acid, and visualized using a JEM 2000 EX transmission electron microscope (TEM) at $80 \mathrm{~V}$ [15]. For immunoelectron microscopy, goldimmunolabeling was performed as described by Levine et al. [16] using 2\% P-formaldehyde (Sigma) fixed cells, anti-13 $\mathrm{kDa}$ protein rat serum (1:10 dilution) and $10 \mathrm{~nm}$ colloidal gold-labeled goat anti-rat IgG (Sigma). To prevent nonspecific labeling, $5 \%$ bovine serum was added to the wash solution.

\subsection{Chicken Oropharyngeal Epithelial Cells (COPEC)}

COPEC were obtained from different chickens by swabbing the oropharyngeal mucosa with a sterile, cottontipped swab and processed as previously described [17]. Cell suspensions were washed five times with $0.1 \mathrm{M}$ Tris-HCl, $\mathrm{pH} 7.2$, to reduce the number of resident bacteria, and adjusted to $2 \times 10^{4}$ cells $/ \mathrm{mL}$ by counting in a Neubauer hemocytometer. Experimental work followed the guidelines of the Norma Oficial Mexicana Guide for the use and care of laboratory animals (NOM-062-ZOO1999).

\subsection{Adhesion Assays}

Adhesion assays were performed as previously described [17]. Briefly, G. anatis $\mathrm{F} 149^{\mathrm{T}}$ were incubated at $37^{\circ} \mathrm{C}$ overnight in BHI medium supplemented with $5 \%$ sheep red blood cells, collected and washed five times with 0.1 
M Tris- $\mathrm{HCl} \mathrm{pH} 7.2$ to remove sheep red blood cells, then re-suspended to a concentration of $7 \times 10^{6} \mathrm{CFU} / \mathrm{mL}$. The number of bacteria attached to each of 40 COPEC was recorded. A negative control consisting of COPEC without bacteria added was used for comparison.

\section{Results}

\subsection{Visualizing Fimbriae by Transmission Electron Microscopy}

Fimbrial structures approximately $1.2 \mu \mathrm{m}$ in length and 5 $\mathrm{nm}$ in width were observed on the surface of $G$. anatis F149 ${ }^{\mathrm{T}}$ (Figures 1(a) and (b), respectively). In addition, bundles of putative thin, long fimbriae $(>3.0 \mu \mathrm{m})$ were visualized. When $G$. anatis $\mathrm{F} 149^{\mathrm{T}}$ surface proteins were extracted and purified, fragments of fimbriae were observed (Figure 1(c)) along with bundles of long pili similar to type IV pili (Figure 1(d)). Long fine fibers were observed protruding from the surface of $G$. anatis $\mathrm{F} 149^{\mathrm{T}}$ by immuno-gold labeling when polyclonal antiserum against the $13 \mathrm{kDa}$ protein was used (Figures 1(e) and (f)).

\subsection{Purification of the Putative Adhesins}

The extracted surface proteins of different sizes $(13,18$, 23,25 and $28 \mathrm{kDa}$ ) were concentrated by precipitation with 2\% polyethylene glycol (Figure 2(a) lanes 2 and 3). When the sample containing the aforementioned proteins was re-precipitated with $6 \%$ polyethylene glycol, two proteins (13 and $25 \mathrm{kDa}$ ) became clearly visible (Figure 2(a), lanes 4 and 5). When electroeluted and re-electrophoresed, the two proteins appeared form multimers at a higher molecular weight; however, if they were electrophoresed in the presence of $3 \mathrm{M}$ urea, they retained their original sizes of 13 and $25 \mathrm{kDa}$.

\subsection{Immunorecognition of Fimbrial Proteins}

Denatured proteins of 13 and $25 \mathrm{kDa}$ were recognized by the serum of chickens that had been experimentally infected with $G$. anatis, suggesting that the proteins had been expressed in vivo. The 13 and $25 \mathrm{kDa}$ bands were recognized individually by their corresponding anti-rat serum (Figure 3(a)), although all the anti-sera also seemed to cross-react weakly with two additional bands of approximately 75 and $60 \mathrm{kDa}$. These two larger bands were mainly recognized if urea was absent during electrophoresis (Figure 3(b)). In the Figure 3, the immune recognition of the $13 \mathrm{kDa}$ protein by three different antisera is shown. Similar results were observed with the $25 \mathrm{kDa}$ protein (data not shown).

\subsection{Adhesion Assays}

When $G$. anatis $\mathrm{F} 149^{\mathrm{T}}$ was incubated with COPEC, the average number of bacteria adhered per cell was $250.1 \pm$ 32.1 , whereas only $35.7 \pm 10.6$ indigenous bacterial cells adhered to each COPEC when no $G$. anatis was added (P $=0.01)$. When bacterial cells were treated with trypsin prior to mixing with epithelial cells, the number of bacteria adhered per cell were similar to the negative controls, indicating that surface proteins participated in adhesion (Table 1). However, when bacterial cells were incubated with antibodies against the $13 \mathrm{kDa}$ protein prior to mixing with epithelial cells, adhesion was not completely inhibited (189 \pm 23 bacteria adhered per cell), indicating that fimbriae formed by this protein are not the unique adhesin that promotes adherence.

\section{Discussion}

In this study, we described the presence of fimbriae on the surface of $G$. anatis and tested their role in adhesion to COPECs. Using negative staining, two different types of fimbriae were observed by TEM. One of the observed fimbriae appear to be a type IV-like pili because of the thin filaments forming bundle structures, similar to other pathogenic microorganisms expressing type IV pili [18]. Type IV fimbriae are considered appendages that participate in motility, microcolony formation, the secretion of proteases and colonization of host tissues [19]. Further characterization of the putative type IV pilus from $G$. anatis is required before its role in host colonization and pathogenesis can be determined.

The different protein bands $(13,18,23,25$ and $28 \mathrm{kDa})$ extracted from $\mathrm{F} 149^{\mathrm{T}}$ could be different components of the same fimbria. All of these bands, including two that were approximately 35 and $50 \mathrm{kDa}$ in size, were recognized by serum from chickens that were experimentally infected with $G$. anatis. This indicated that these proteins are immunogenic and expressed in vivo. Several of these proteins were also recognized by the sera against the 13 and $25 \mathrm{kDa}$ proteins, suggesting there is immune crossreactivity between them. Hyperimmune serum against the $13 \mathrm{kDa}$ protein joined to long, thin fibers located on the surface of $G$. anatis when immunogold electron microscopy was used. This indicates that the $13 \mathrm{kDa} G$. anatis protein is either part of or constitutes a putative fimbrial subunit. Although thicker fimbriae were also observed by electron microscopy, these were not identified by immunogold-labeled antibodies against the 13 $\mathrm{kDa}$ protein. This result suggests that more than one type fimbria exists on the surface of $G$. anatis.

In this work, we show that $G$. anatis $\mathrm{F} 149^{\mathrm{T}}$ is able to attach to COPEC in numbers $\geq 250$ bacteria per cell, whereas an average of 35 were observed as indigenous bacteria. This bacterial attachment was blocked if $G$. anatis cells were pretreated with trypsin, indicating that surface proteins take part in this process. Thus, it is probable that the adhesion of $G$. anatis, as with other 


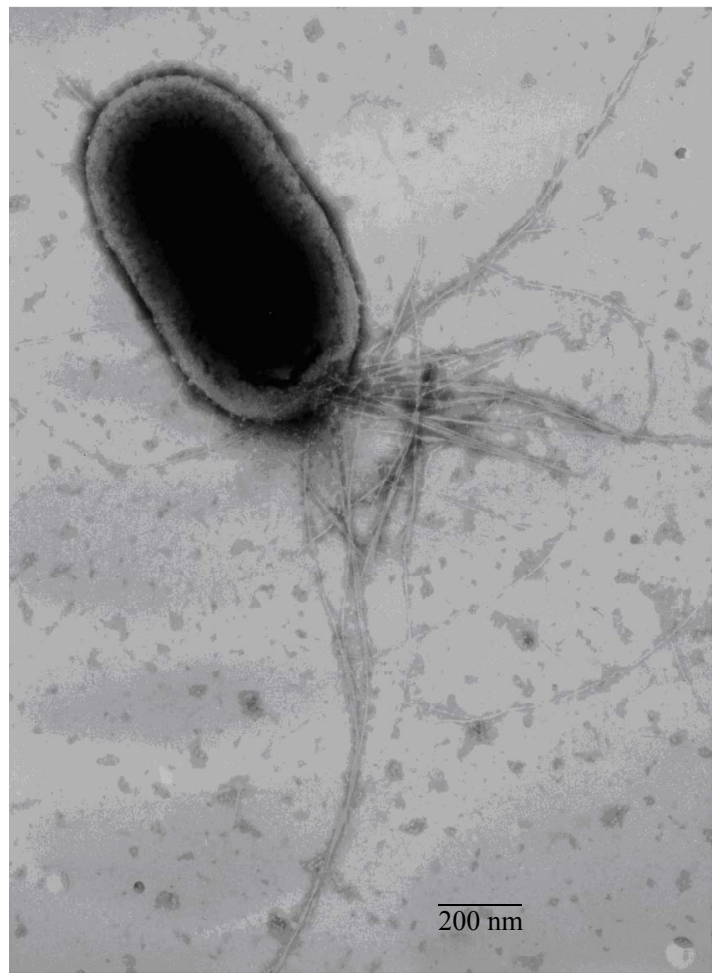

(a)

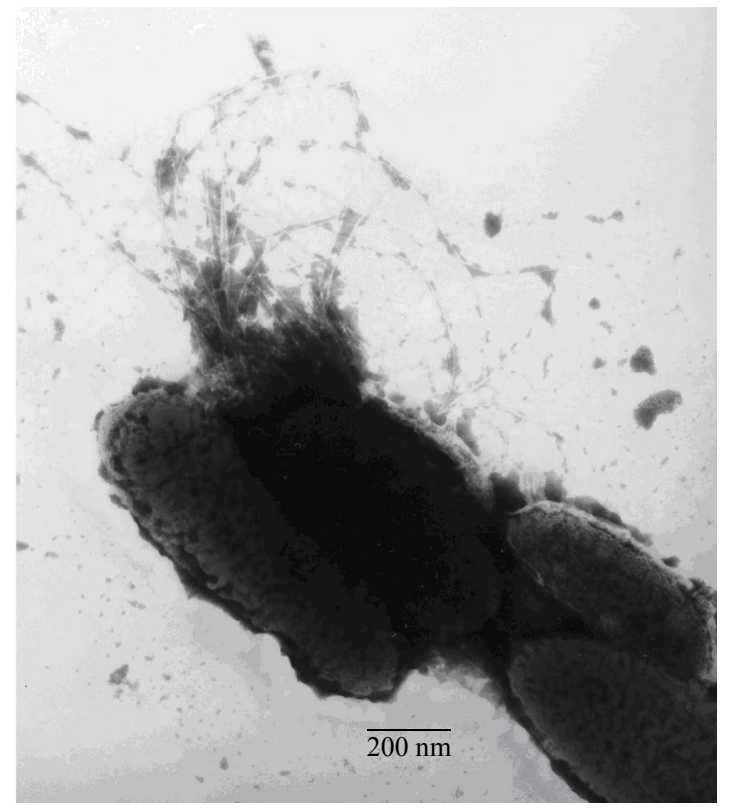

(b)

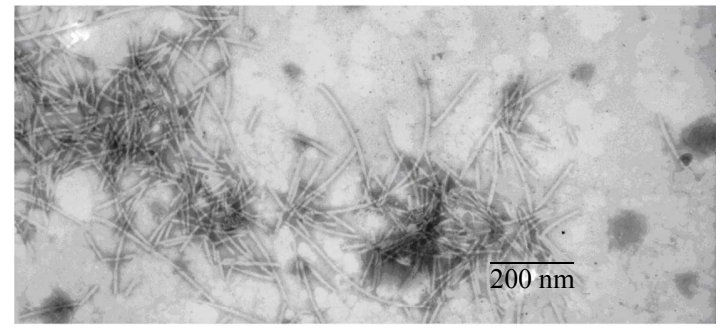

(c)

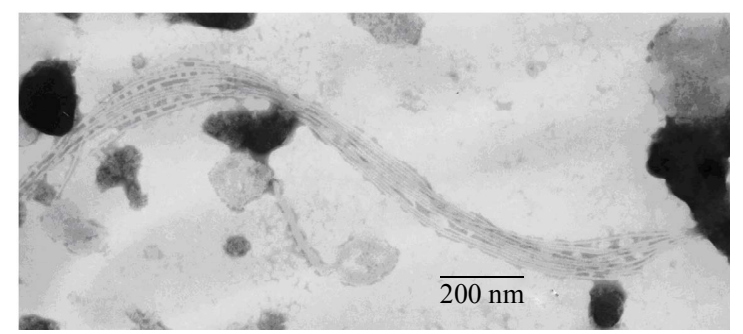

(d)

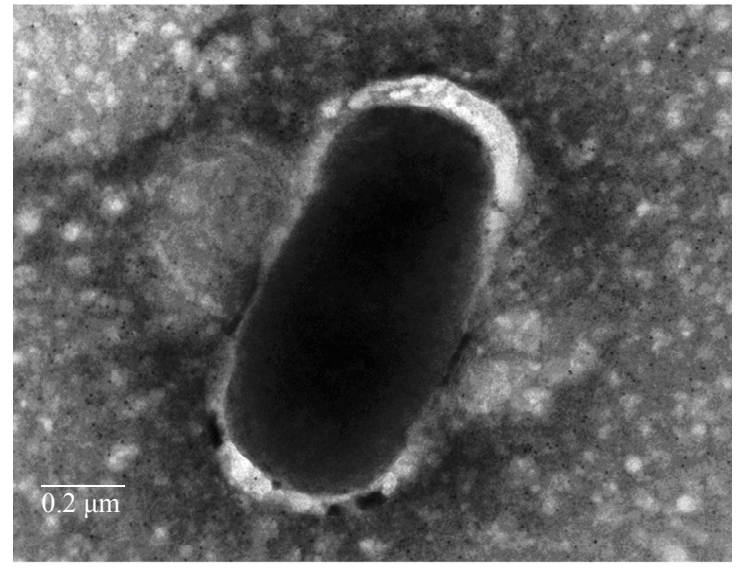

(e)

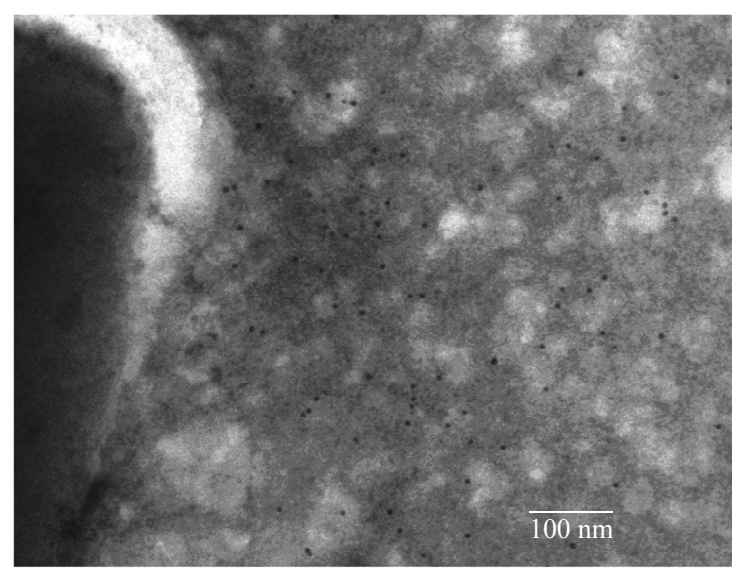

(f)

Figure 1. Electron micrographs showing fimbriae on the bacterial surface of $G$. anatis $F 149^{\mathrm{T}}$ (a) and (b), and fimbriae released after shaking the bacteria and concentrated by precipitation with PEG (c) and (d). In parts (e) and (f), the immunogold labeling using the polyclonal serum against the $13 \mathrm{kDa}$ protein from $G$. anatis can be visualized.

bacteria, is the first step in tissue colonization [20].

Treatment of $G$. anatis cells with serum against the 13 $\mathrm{kDa}$ protein diminished bacterial adhesion to COPEC by 25\% (Table 1), indicating that bacterial adhesins other than the $13 \mathrm{kDa}$ protein also participate in the adhesion of $G$. anatis to COPEC. This interpretation is in good agreement with the four annotated genes encoding putative fimbrial proteins in the genome of the hemolytic strain G. anatis $12656-12$. It would be very useful to ob- 


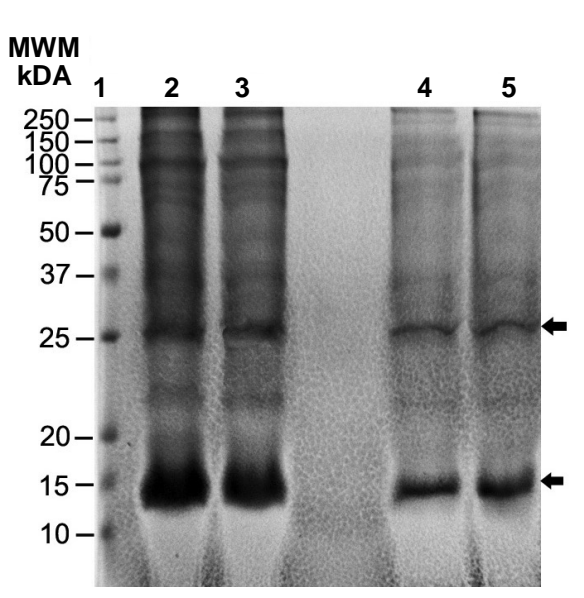

(a)

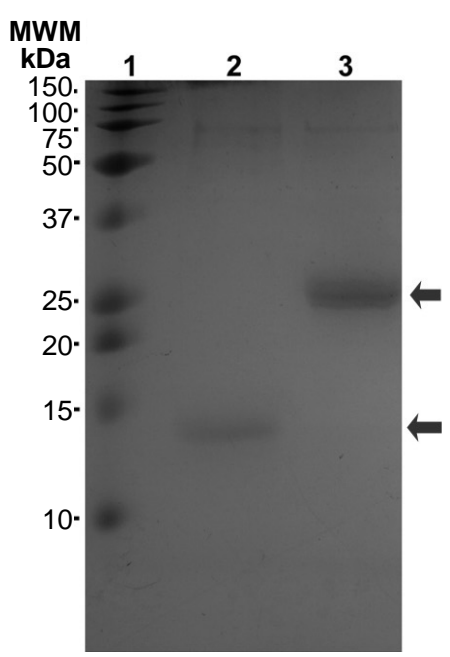

(b)

Figure 2. Purification of adhesions: (a) Fimbriae preparations electrophoresed in 15\% polyacrylamide gels. Lanes 2 and 3 correspond to two different samples precipitated with $2 \%$ PEG; lanes 4 and 5 correspond to the same samples after precipitation with 6\% PEG. Arrows indicated the 13 and 25 kDa proteins; (b) 13 and 25 kDa proteins bands electroeluted and electrophoresed in the presence of $3 \mathrm{M}$ urea.

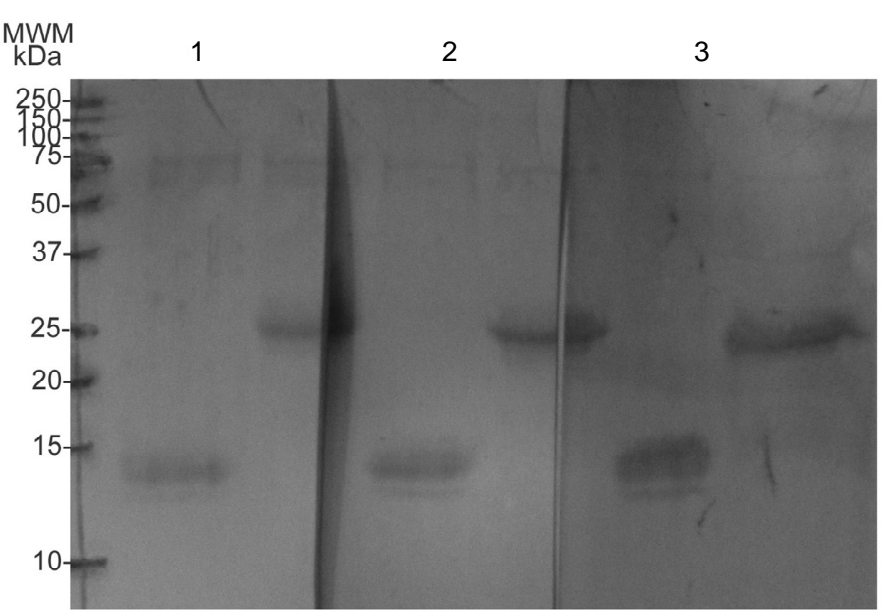

(a)

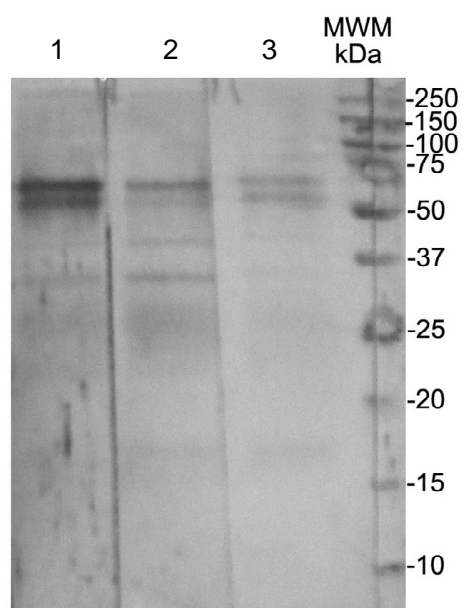

(b)

Figure 3. Immune recognition of the putative fimbrial proteins electroeluted and re-electrophoresed with (a) or without (b) 3 $M$ urea using 1): Serum from chickens experimentally infected with G. anatis; 2): Rat serum anti-13 kDa protein; and 3): Rat serum anti-25 kDa protein.

Table 1. Adhesion of $G$. anatis to chicken oropharyngeal epithelial cells.

\begin{tabular}{ccc}
\hline Strain added & Treatment & Number of bacteria per cell Mean \pm SD \\
\hline None & None & $35.7 \pm 10.6$ \\
& None & $250.1 \pm 32.1^{*}$ \\
Gallibacterium $_{\text {anatis F149 }}$ & Trypsin & $36.2 \pm 11.5$ \\
& Anti-13 & $189.5 \pm 23.2$ \\
\hline
\end{tabular}

*Significantly different from negative control $(\mathrm{P}=0.01)$.

tain a $G$. anatis mutant deficient in the $13 \mathrm{kDa}$ protein and compare its adhesion to COPEC against the wild type strain in order to determine the role of the $13 \mathrm{kDa}$ protein in adhesion. We are currently working towards generating $G$. anatis mutants deficient in the four putative fimbrial proteins.

We also observed that the 13 and $25 \mathrm{kDa}$ proteins have auto-aggregative properties because when they were eluted from a polyacrylamide gel and re-electrophoresed, bands were observed at higher molecular weights (75 to $60 \mathrm{kDa}$ ), suggesting oligomerization of these proteins. The 75 - $60 \mathrm{kDa}$ bands were also recognized by the polyclonal sera against the 13 or $25 \mathrm{kDa}$ proteins, and by the serum from chickens experimentally infected with $G$. anatis (Figure 3(b)). However, when the proteins were electrophoresed in the presence of a denaturing agent such as urea, they conserved their molecular weight, in- 
dicating that the larger proteins could be multimers comprising one or two protein types.

The presence of putative fimbria on the surface of $G$. anatis could contribute to chicken tissue adhesion and the potential to infect susceptible hosts

\section{Acknowledgements}

This work was supported by DGAPA-UNAM, Projects PAPIIT IN216010, and PAPCA-FES-Iztacala. We thank Jose Molina and Lourdes Rojas from the Electron Microscopy Laboratory of CINVESTAV-IPN for their technical assistance.

\section{REFERENCES}

[1] A. M. Bojesen, S. S. Nielsen and M. Bisgaard, "Prevalence and Transmission of Haemolytic Gallibacterium Species in Chicken Production Systems with Different Biosecurity Levels," Avian Patholology, Vol. 32, No. 5, 2003, pp. 503-510. doi:10.1080/0307945031000154107

[2] H. Christensen, M. Bisgaard, A. M. Bojesen, R. Mutters and J. E. Olsen, "Genetic Relationships among Avian Isolates Classified as Pasteurella haemolytica, Actinobacillus salpingitidis or Pasteurella anatis with Proposal of Gallibacterium anatis gen. nov., comb. nov. and Description of Additional Genomospecies within Gallibacterium gen. nov.," International Journal of Systematic and Evolutionary Microbiology, Vol. 53, No. 1, 2003, pp. 275287. doi:10.1099/ijs.0.02330-0

[3] A. M. Bojesen and H. L. Shivaprasad, "Genetic Diversity of Gallibacterium Isolates from California Turkeys," Avian Pathology, Vol. 36, No. 3, 2007, pp. 227-230. doi:10.1080/03079450701332352

[4] M. Bisgaard, "Incidence of Pasteurella haemolytica in the Respiratory Tract of Apparently Healthy Chickens and Chickens with Infectious Bronchitis. Characterization of 213 Strains," Avian Pathology, Vol. 6, No. 4, 1977, pp. 285-292. doi:10.1080/03079457708418238

[5] R. Mushin, Y. Weisman and N. Singer, "Pasteurella haemolytica Found in the Respiratory Tract of Fowl," Avian Diseases, Vol. 24, No. 1, 1979, pp. 162-168. doi: $10.2307 / 1589775$

[6] P. B. Addo and K. Mohan, "Atypical Pasteurella haemolytica Type A from Poultry," Avian Diseases, Vol. 29, No. 1, 1985, pp. 214-217. doi:10.2307/1590710

[7] C. Neubauer, M. De Souza-Pilz, A. M. Bojesen, M. Bisgaard and M. Hess, "Tissue Distribution of Haemolytic Gallibacterium anatis Isolates in Laying Birds with Reproductive Disorders," Avian Pathology, Vol. 38, No. 1, 2009, pp. 1-7. doi:10.1080/03079450802577848

[8] E. García-Gómez, S. Vaca, A. Pérez-Méndez, J. IbarraCaballero, V. Pérez-Márquez, V. R. Tenorio and E. Negrete-Abascal, "Gallibacterium anatis-Secreted Metallo Proteases Degrade Chicken IgG," Avian Patholology, Vol. 34, No. 5, 2005, pp. 426-429. doi:10.1080/03079450500267866

[9] A. Zepeda, S. Ramírez, V. Vega, V. Morales, M. Talavera,
C. Salgado-Miranda, J. Simón-Martínez, A. M. Bojesen and E. Soriano-Vargas, "Hemagglutinating Activity of Gallibacterium Strains," Avian Diseases, Vol. 53, No. 1, 2009, pp. 115-118. doi:10.1637/8375-060908-ResNote.1

[10] B. M. Kristensen, D. Frees and A. M. Bojesen, "GtxA from Gallibacterium anatis, a Cytolytic RTX-Toxin with a Novel Domain Organization," Veterinary Research, Vol. 41, No. 3, 2010, p. 25. doi:10.1051/vetres/2009073

[11] B. M. Kristensen, D. Frees and A. M. Bojesen, "Expression and Secretion of the RTX-Toxin GtxA among Members of the Genus Gallibacterium," Veterinary Microbiolology, Vol. 153, No. 1-2, 2011, pp. 116-123. doi:10.1016/j.vetmic.2011.05.019

[12] S. Vaca, E. Monroy, L. Rojas, C. Vázquez, P. Sánchez, E. Soriano-Vargas, A. M. Bojesen and E. Negrete Abascal, "Adherence of Gallibacterium anatis to Inert Surfaces," Journal of Animal Veterinary Advances, Vol. 10, No. 13, 2011, pp. 1688-1693. doi:10.3923/javaa.2011.1688.1693

[13] S. M. Kirov, K. Sanderson and T. C. Dickson, "Characterization of a Type IV Pilus Produced by Aeromonas caviae," Journal of Medical Microbiology, Vol. 47, No. 6, 1998, pp. 527-531. doi:10.1099/00222615-47-6-527

[14] U. K. Laemmli, "Cleavage of Structural Proteins during the Assembly of the Head of Bacteriophage T4," Nature, Vol. 227, No. 5259, 1970, pp. 680-685. doi: $10.1038 / 227680 \mathrm{a} 0$

[15] E. Negrete-Abascal, M. E. Reyes, R. M. García, S. Vaca, J. A. Girón, O. García, E. Zenteno and M. de la Garza, "Flagella and Motility in Actinobacillus pleuropneumoniae," Journal of Bacteriology, Vol. 185, No. 2, 2003, pp. 664-668. doi:10.1128/JB.185.2.664-668.2003

[16] M. M. Levine, P. Ristaino, G. Marley, C. Smyth, S. Knutton, E. Boedeker, R. Black, C. Young, M. L. Clements, C. Cheney and R. Patnaik, "Coli Surface Antigens 1 and 3 of Colonization Factor Antigen II-Positive Enterotoxigenic Escherichia coli: Morphology, Purification, and Immune Responses in Humans," Infection and Immunity, Vol. 44, No. 2, 1984, pp. 409-420.

[17] S. Vaca, G. O. García and C. G .L. Paniagua, "The Lom Gene of Bacteriophage $\lambda$ Is Involved in Escherichia coli K12 Adhesion to Human Buccal Epithelial Cells," FEMS Microbiology Letters, Vol. 156, No. 1, 1997, pp. 129-132. doi:10.1111/j.1574-6968.1997.tb12717.x

[18] L. Craig, M. E. Pique and J. A. Tainer, "Type IV Pilus Structure and Bacterial Pathogenicity," Nature Reviews Microbiology, Vol. 2, No. 5, 2004, pp. 363-378. doi:10.1038/nrmicro885

[19] L. Craig and J. Li, "Type IV Pili: Paradoxes in Form and Function," Current Opinion in Structural Biology, Vol. 18, No. 2, 2008, pp. 267-277. doi:10.1016/j.sbi.2007.12.009

[20] R. Hamer-Barrera, D. Godínez, V. I. Enríquez, S. VacaPacheco, R. Martinez-Zúñiga, P. Talamás-Rohana, F. Suárez-Güemez and M. de la Garza, "Adherence of Actinobacillus pleuropneumoniae Serotype 1 to Swine Buccal Epithelial Cells Involves Fibronectin," Canadian Journal of Veterinary Research, Vol. 68, No. 1, 2004, pp. 33-41. 